\title{
CORONARY ARTERY VASOSPASM SECONDARY TO TYPE I VARIANT KOUNIS SYNDROME: A CASE SERIES OF MEN. IS THE GENDER DIFFERENCES IMPORTANT?
}

\author{
Cuneyt Kocas ${ }^{1}$, Ahmet Cagri Aykan ${ }^{2}$, Okay Abaci ${ }^{1}$, Gokhan Cetinkal ${ }^{1}$, Sukru Arslan ${ }^{1}$, Mustafa Yildiz ${ }^{1}$
}

Kounis syndrome is a well-known cause of acute coronary syndrome and more than 100 cases are reported with allergic reactions to various drugs, animal and insect bites, even with drug eluting stents and endovascular devices. In this paper we report five-patients with Kounis syndrome related to different drugs. The main characteristic of patients is given in Table 1. All of them were male and their age was from 18 to 35 . All patients presented with ST- elevation myocardial infarction. Coronary angiography was performed in all patients and revealed normal coronary arteries. From history of allergic exposure, electrocardiographic, laboratory (Total $\lg E$ and tryptase levels) and angiographic findings the diagnosis was Kounis syndrome type I for all patients and was treated with oral antihistamines and prednisolone. Despite Type $1 \mathrm{KS}$ is not associated with atherosclerotic risk factors and CAD all patients in or report and many patients in literature are male. Gender differences in KS should be investigated in further studies.

Russ J Cardiol 2014, 4 (108), Engl.: 66-67
Key words: Kounis syndrome, gender.

'Department of Cardiology, Istanbul University Cardiology Institute, Istanbul; ${ }^{2}$ Department of Cardiology, Kartal Kosuyolu Educational and Reseach Hospital, Istanbul, Turkey.

Corresponding author. Cuneyt Kocas, MD, Istanbul University Institute of Cardiology, Department of Cardiology, Cardiologist, Instructor; Haseki, Aksaray 34350, Istanbul/Turkey, Tel: +905059383527, Fax: +902164693796, e-mail: cuneytkocas@hotmail.com

Received June 09, 2013

Revision received June 11, 2013.

Accepted June 18, 2013

\section{ВАЗОСПАЗМ КОРОНАРНЫХ АРТЕРИЙ СРЕДНЕГО ТИПА І ВАРИАНТ КОUNIS СИНДРОМА: СЕРИЯ СЛУЧАЕВ У МУЖЧИН. ВАЖНЫ ЛИ ГЕНДЕРНЫЕ РАЗЛИЧИЯ?}

Cuneyt Kocas ${ }^{1}$, Ahmet Cagri Aykan ${ }^{2}$, Okay Abaci ${ }^{1}$, Gokhan Cetinkal ${ }^{1}$, Sukru Arslan ${ }^{1}$, Mustafa Yildiz ${ }^{1}$

Kounis-синдром является известной причиной острого коронарного синдрома и сообщается о более 100 случаях заболевания при аллергических реакциях на различные препараты, укусы животных и насекомых, даже на стенты с лекарственным покрытием и эндоваскулярные устройства. В этой статье мы докладываем о пяти пациентах с синдром Kounis, по отношению к различным лекарствам. Главная характеристика больных приведена в Таблице 1. Все они были мужчинами, и их возраст от 18 до 35 лет. У всех пациентов представлен инфаркт миокарда с подъемом ST. Коронарная ангиография выявила у всех больных нормальные коронарные артерии. Из истории аллергического воздействия, электрокардиографических, лабораторных (Общий IgE и уровни триптазы)

\section{Introduction}

The first paper in the literature, examining the acute myocardial infarction (MI) related to prolonged allergic reaction was published in 1950 [1]. But the definition of Kounis syndrome (allergic angina) was in 1991 as "the coincidental occurrence of chest pain and allergic reactions accompanied by clinical and laboratory findings of classic angina pectoris caused by inflammatory mediators released during the allergic insult" [2]. In 1996 "allergic myocardial infarction" term was defined in literature [3]. As today, Kounis syndrome is a wellknown cause of acute coronary syndrome and more than 100 cases are reported with allergic reactions to various drugs (antibiotics, analgesics, antineoplastics, contrast media, intravenous anaesthetics, no steroidal anti-inflammatory drugs, anticoagulants, proton pump inhibitors), animal and insect bites, even with drug eluting stents and endovascular devices [4, 5].

\section{Case Descriptions}

In this paper we report five-patients with Kounis syndrome related to different drugs. The main characteristic of patients is given in Table 1. All of them were male and their age was from 18 to 35 . Main symptom was chest pain in all patients whereas и ангиографических данных, был поставлен диагноз синдрома Kounis типа I для всех пациентов, которых лечили перорально антигистаминными препаратами и преднизолоном. Несмотря на то, что синдром Kounis типа I не связан с факторами риска атеросклероза и ИБС, все пациенты в отчетах, и многие пациенты, описанные в литературе, являются мужчинами. Гендерные различия синдрома Kounis должны быть изучены в ходе дальнейших исследований.

Российский кардиологический журнал 2014, 4 (108), Англ.: 66-67

Ключевые слова: Kounis синдром, пол.

dyspnoea was present in case 1 and pruritus was also accompanied in case 2. All patients presented with ST- elevation myocardial infarction, case 1,3 and 5 with anterior MI, case 2 inferior MI and case 4 with inferolateral MI. Troponin levels were increased in all patients, total immunoglobulin E (IgE) levels were also increased in all of them, tryptase level could be measured in two cases (Case 2 and 5) and elevated. Whole blood count, D-dimer, antithrombin III, serum cholesterol levels, C3 and C4 levels and antinuclear antibody, anti-DNA tests were within normal limits. The reasons of Kounis syndrome were metimazol sodium in case 1 , gadopentetic acid in case 2, amoxicillin/clavulanic acid in case 3 and case 5, acetaminophen in case 4 . The medical history for bronchial asthma, any allergic disease or coronary artery disease was negative. The serologic tests for viral aetiology were also negative. Coronary angiography was performed in all patients and revealed normal coronary arteries. From history of allergic exposure, electrocardiographic, laboratory (Total IgE and tryptase levels) and angiographic findings the diagnosis was Kounis syndrome type I for all patients and was treated with oral antihistamines and prednisolone. All symptoms electrocardiographic and echocardiographic findings were resolved by the time of discharge. 


\section{The characteristics of patients with Kounis syndrome}

\begin{tabular}{|c|c|c|c|c|c|}
\hline & Patient 1 & Patient 2 & Patient 3 & Patient 4 & Patient 5 \\
\hline Age, years & 33 & 35 & 31 & 24 & 18 \\
\hline Sex & M & $M$ & $M$ & $M$ & $M$ \\
\hline Atopy & No & No & No & No & No \\
\hline CVRF & No & No & No & No & No \\
\hline Symptoms & Dyspnoea, chest pain & Pruritis, chest pain & Chest pain & Chest pain & Chest pain \\
\hline Allergic cause & Metamizol $500 \mathrm{mg}$ & Gadopentetic acid $20 \mathrm{ml}$ & $\begin{array}{l}\text { Amoxicillin/ Clavulanic acid } \\
1000 \mathrm{mg}\end{array}$ & Acetaminophen $500 \mathrm{mg}$ & $\begin{array}{l}\text { Amoxicillin Clavulanic acid } \\
1000 \mathrm{mg}\end{array}$ \\
\hline ST segment elevation & Anterior & Inferior & Anterior & Inferolateral & Anterior \\
\hline Trop I (ng/ml) & 40 & 13 & 15 & 46 & 50 \\
\hline Total lgE (0-100 IU/ml) & 190 & 117 & 120 & 202 & 350 \\
\hline $\begin{array}{l}\text { Tryptase (5.6-13.5 } \\
\mu \mathrm{g} / \mathrm{L})\end{array}$ & - & 20 & - & - & 45 \\
\hline CAG & Normal & Normal & Normal & Normal & Normal \\
\hline
\end{tabular}

Abbreviations: CVRF - cardiovascular risk factors, Trop I - troponine I, CAG - coronary angiography.

\section{Discussion}

Kounis syndrome was defined as an acute coronary syndrome that manifests as unstable vasospastic or nonvasospastic angina, and even as acute myocardial infarction triggered by inflammatory mediators following exposure to an allergic insult. There are currently 3 variants of Kounis syndrome [6]. The first variant is observed in patients with no cardiovascular risk factors and normal coronary arteries in whom acute release of inflammatory mediators such as histamine and leukotriens can trigger coronary spasm [7]. In Type-II variant of KS include patients with pre-existing atheromatous disease in whom acute release of these mediators can induce coronary artery spasm or rupture of atheromatous plaque. Recently, Type- III variant of Kounis syndrome has been defined in subjects with drug eluting coronary stent thrombosis [4]. In this variant stent components (nickel strut, polymer or impregnated drug) may play a role as allergic insult [8]. All of our patients were Type 1 Kounis syndrome. Several pathophysiologic mechanisms have been described to explain the association between an allergic reaction and acute coronary syndrome [6]. Mast cell degranulation follows after antibody antigen complex or sometimes allergen itself may start degranulation. After mast cell degranulation vasoconstricting and collagen degrading mediators such as, histamine, neutral proteases (tryptase, chymase), platelet activating factor and newly

\section{References}

1. Pfister $\mathrm{CW}$, Plice SG. Acute myocardial infarction during a prolonged allergic reaction to penicillin. Am Heart J 1950;40:945-7.

2. Kounis NG, Zavras GM. Histamine-induced coronary artery spasm: the concept of allergic angina. Br J Clin Pract 1991;45:121-8.

3. Kounis NG, Zavras GM. Allergic angina and allergic myocardial infarction. Circulation 1996;94:1789.

4. Akyel A, Murat SN, Cay S, Kurtul A, Ocek AH, Cankurt T. Late drug eluting stent thrombosis due to acemetacine: type III Kounis syndrome: Kounis syndrome due to acemetacine. Int J Cardiol 2012;155:461-2

5. Almpanis GC, Tsigkas GG, Koutsojannis C, Mazarakis A, Kounis GN, Kounis NG. Nickel allergy, Kounis syndrome and intracardiac metal devices. Int J Cardiol 2010;145:364-5. synthesized mediators are released locally and in the peripheral circulation [9]. These mediators appear to affect the myocardium directly. Histamine, through its $\mathrm{H} 1$ receptors, mediates coronary artery vasoconstriction, and increases vascular permeability, whereas activation of $\mathrm{H} 2$ receptors causes inotropic, chronotropic effects [10, 11]. Histamine can also activate platelets and potentiates aggregatory response. Tryptase level was elevated in two patients but not applicable in other patients. Total IgE levels were increased in all patients and this result may be the reflector of an allergic reaction. All patients in our report are male. CAD frequency is higher in male compared to female but Type $1 \mathrm{KS}$ is not associated with atherosclerosis and defined as $\mathrm{KS}$ with normal coronary arteries. Although previous reports have shown mortality or malignant course of Kounis syndrome [4], our patients had an uneventful in-hospital course.

\section{Conclusion}

Although the exact pathophysiologic mechanism of Kounis syndrome is not clear, the increasing number of reports published in the last few year's points that this syndrome should be kept in mind for consideration in the differential diagnosis of ischemic heart disease especially in young patients without cardiac risk factors and concomitant allergic symptoms. Gender differences in KS should be investigated in further studies.

11. Raper RF, Fisher MM (1988) Profound reversible myocardial depression after anaphylaxis. Lancet 1988;1:386-8. 